University of Nebraska - Lincoln

DigitalCommons@University of Nebraska - Lincoln

\title{
Evaluation of genetic markers for prediction of preharvest sprouting tolerance in hard white winter wheats
}

\author{
Robert A. Graybosch \\ University of Nebraska-Lincoln, bob.graybosch@ars.usda.gov \\ Paul St. Amand \\ USDA-ARS-HWWGRU, paul.stamand@ars.usda.gov \\ Guihua Bai \\ USDA-ARS, guihua.bai@ars.usda.gov
}

Follow this and additional works at: https://digitalcommons.unl.edu/usdaarsfacpub

Graybosch, Robert A.; St. Amand, Paul; and Bai, Guihua, "Evaluation of genetic markers for prediction of preharvest sprouting tolerance in hard white winter wheats" (2013). Publications from USDA-ARS / UNL Faculty. 1252.

https://digitalcommons.unl.edu/usdaarsfacpub/1252

This Article is brought to you for free and open access by the U.S. Department of Agriculture: Agricultural Research Service, Lincoln, Nebraska at DigitalCommons@University of Nebraska - Lincoln. It has been accepted for inclusion in Publications from USDA-ARS / UNL Faculty by an authorized administrator of DigitalCommons@University of Nebraska - Lincoln. 


\title{
Evaluation of genetic markers for prediction of preharvest sprouting tolerance in hard white winter wheats
}

\author{
Robert A. Graybosch ${ }^{1,3}$, Paul St. Amand ${ }^{2}$ and Guinua Bai ${ }^{2}$ \\ ${ }^{1}$ USDA-ARS, 137 Keim, University of Nebraska, Lincoln, NE 68583, USA; ${ }^{2}$ USDA-ARS-HWWGRU 4008 Throckmorton Hall, \\ Kansas State University, Manhattan, KS 66506, USA; ${ }^{3}$ Corresponding author, E-mail: bob.graybosch@ars.usda.gov
}

With 2 figures and 7 tables

Received September 10, 2012/Accepted March 11, 2013

Communicated by $H$. Bürstmayr

\begin{abstract}
Preharvest sprouting of wheat results in significant financial loss at all steps in the production and marketing chain. Due to its intermittent nature in many wheat-growing regions, direct selection for tolerance to preharvest sprouting is difficult. DNA markers linked to genes conditioning tolerance offer a more consistent and reliable approach to genetic improvement in tolerance. This investigation assessed the value of previously identified markers linked to quantitative trait loci contributing to tolerance, across multiple genetic backgrounds. A significant contribution to tolerance was demonstrated for QPhs.pseru-3AS, previously identified from the hard white winter wheat 'Rio Blanco'. Marker alleles for this locus were associated with enhanced tolerance in three of four investigated populations. In addition, positive contributions of QPhs.pseru-2B1 and QPhs.pseru-2B2 also were documented. Simultaneous selection for putative marker alleles at two independent loci resulted in significantly higher mean tolerance scores. DNA markers linked to loci contributing to variation in preharvest sprouting tolerance offer an efficient and effective alternative to direct phenotypic selection.
\end{abstract}

Key words: wheat - pre harvest sprouting — DNA markers chromosome 3AS — 'Rio Blanco'

Humid conditions during grain ripening can induce preharvest sprouting in wheat (Triticum aestivum L.). Preharvest sprouting results in the release of starch- and protein-degrading enzymes, with a concomitant loss of functional properties and seed quality (Brijs et al. 2009). Preharvest sprouting may be encountered wherever wheat is cultivated, and is a factor of consideration in nearly every grading system (Ross and Bettge 2009). Financial impacts can be severe; for example, DePauw et al. (2012) estimated annual financial loss to the Canadian wheat crop of approximately $\$ 100$ million per year. Selection for improved tolerance to preharvest sprouting is a goal of wheat breeding programmes worldwide.

From the onset of modern agriculture in the Great Plains of North America, wheat production has been dominated by hard red winter and spring wheats. However, over the past 2030 years, breeding programmes initiated and continued the development of hard white wheats. White wheats have utility in two primary markets. They are used in the domestic production of whole wheat breads and are the preferred wheat of commerce in a number of export markets, especially for use in the production of Asian wet noodles. Red-grained wheat is, in general, more resistant to preharvest sprouting than white wheat (Morris and Paulsen 1992). Before the onset of white wheat development efforts, selection for tolerance in the US portion of the Great
Plains was opportunistic at best. The development of hard white wheats in the area necessitated the need for deliberate selection for this trait. While natural preharvest sprouting events might occur at some locations in the Great Plains each year, no one locale consistently is visited by such ill fortune. Thus, artificial means of induction of sprouting and selection for tolerance have been developed. Tolerance may be assessed by the use of misting systems and subsequent determination of $\alpha$-amylase activity (Clarke et al. 2005) or other measures of starch quality (Ross and Bettge 2009). Such approaches, however, are difficult to employ as error frequencies encountered with field-grown materials often are high. Alternative approaches include germination studies of seed harvested at physiological maturity and rapidly dried (Wu and Carver 1999) or germination of such seed in the presence of the germination inhibitor abscisic acid (ABA) (Morris et al. 1989).

Selection based on DNA markers offers an alternative approach to the identification of tolerant lines in breeding programmes. A number of studies aimed at identifying markers linked to quantitative trait loci (QTLs) contributing to enhanced tolerance have been reported (Kato et al. 2001, Kulwal et al. 2005, Mares et al. 2005, Kottearachchi et al. 2006, Tan et al. 2006, Singh et al. 2010, 2012). QTLs associated with tolerance have been found on many chromosomes (Mares and Mrva 2001). Chromosomes 2B, 3A and 4A most frequently have been identified as those harbouring genes linked to tolerance. Markers linked to QTLs conditioning tolerance to preharvest sprouting also have been identified in other members of the Poaceae (Xie et al. 2011).

Genetic diversity does exist among both Great Plains red- and white-seeded wheats for sprouting tolerance ( $\mathrm{Wu}$ and Carver 1999). Among hard white winter wheats, the cultivar 'Rio Blanco' has been reported to be among the most tolerant (Wu and Carver 1999). Liu et al. (2008) recently identified a QTL (QPhs.pseru-3AS) on chromosome 3A of Rio Blanco-derived populations that explained up to $58 \%$ of the phenotypic variation for tolerance to preharvest sprouting using greenhouse-grown materials. Previously, Kottearachchi et al. (2006), using some of the same simple sequence repeat (SSR) markers, had identified a QTL on the same chromosome designated QPhs-3AS QTL. In recombinant inbred lines derived from the cross 'Zen'/'Spica', some white-seeded progeny with the favourable allele at $Q P h s-$ $3 A S Q T L$ had levels of dormancy equal to those of red-grained lines. Both QPhs-3AS QTL of Kottearachchi et al. (2006) and QPhs.pseru-3AS of Liu et al. (2008) were tightly linked to the SSR marker Xbarc321, suggesting not only the identification of 
the same QTL but also the significant observation that the locus is present in the diverse wheat gene pools derived from Japan and the Great Plains of North America.

Kulwal et al. (2005) observed inconsistent detection of preharvest sprouting tolerance across cultural environments. Thus, it is important to verify the utility of selection for the 3AS Rio Blanco-derived QTL in field-grown materials. Furthermore, for marker-assisted selection to be effective, markers need to be identified that allow selection across a range of genetic backgrounds (DePauw et al. 2012). Liu et al. (2008) investigated two genetic populations derived from 'Rio Blanco'. Observations in additional populations would further document the utility of selection for a given QTL.

The goal of this study was to verify the relationship between the Rio Blanco-derived 3AS QTL and additional QTLs on chromosomes 2B (QPhs.pseru-2B1 and QPhs.pseru-2B2, Liu et al. 2008) and 4A (Phs1; Mares et al. 2005, Torada et al. 2008) contributing to enhanced tolerance in field-grown materials, in different genetic backgrounds and across harvest seasons. DNA markers were tested to (i) determine whether alternative QTLs had greater effects than the Rio Blanco-derived 3AS QTL and (ii) establish whether combined selection for two unlinked QTLs would provide more effective discrimination of tolerant genotypes.

\section{Materials and Methods}

Plant materials and field experiments: Four breeding populations were developed with the following pedigrees: 'Nuplains'/'Arrowsmith', NW98S061/'Rio Blanco', NW97S186/'Rio Blanco' and 'Rio Blanco'/ NW97S218. 'Rio Blanco' (Plant Variety Protection Certificate Number 8900120), as noted above, is a hard white winter wheat with tolerance to preharvest sprouting. 'Nuplains' (Plant Variety Protection Certificate Number 200100266) also is a hard white winter wheat tolerant to preharvest sprouting with the pedigree 'Abilene'/3/'Plainsman V'/l 'Newton'/'Arthur 71'. According to records of the USDA ARS National Small Grains Collection (http://www.ars-grin.gov/npgs/index.html), 'Rio Blanco' and 'Abilene' have similar, and perhaps identical, pedigrees. That of 'Rio Blanco' is listed as OK11252A/W76-1226, while 'Abilene's pedigree is described as OK11252/W76-1226. Thus, 'Nuplains' and 'Rio Blanco' might share common genes for tolerance to preharvest sprouting. Arrowsmith (Graybosch et al. 2005) is a hard white wheat susceptible to preharvest sprouting. NW97S186, NW98S061 and NW97S218 are susceptible hard white winter wheats developed by the USDA ARS at Lincoln, NE. The NW97S186/Rio Blanco population previously was evaluated in the study of Liu et al. (2008) in three greenhouse experiments and one field-grown study conducted in the year 2005. In the present study, this population was evaluated in an additional four harvest seasons, using field-grown materials.

Populations were advanced in-bulk until the $\mathrm{F}_{3}$ generation. From the $F_{3}$ populations, single-head selections were made and planted in 1-m $F_{4}$ head-rows. From each $\mathrm{F}_{4}$ head-row, a single head was harvested and again planted in a 1-m single-plant progeny row in 2005. Each single-plant row was harvested and used to seed a four-row 1.2 by $2.4 \mathrm{~m}$ plot in the field in 2006. At least 92 individual lines were evaluated in each population. Each 2006 plot was harvested with a mechanical combine and used to seed identical sized plots in 2007. Plots were harvested in a similar manner each year and replanted from 2008 to 2010. Screening for tolerance to preharvest sprouting occurred in crop years 2007-2010 $\left(\mathrm{F}_{7}-\mathrm{F}_{10}\right.$ generations). Entries from all four populations were planted in a completely random unreplicated design each year. Parents and control cultivars were seeded each year in replicated plots, with at least three replications per year. In addition to the parents, the following hard white winter wheat controls were planted: 'Trego', 'Anton', Arrowsmith, 'Antelope' and 'Platte'. Also included were the hard red winter wheats 'Camelot', 'Wesley', 'Jagalene', 'Overland', 'Arapahoe' and 'Prong- horn'. Days from $1 / 1$ to heading (day on which $50 \%$ of the heads in a plot were fully emerged from the boot) were recorded for all entries each season. All field studies were conducted at the University of Nebraska Agricultural Research and Development Center, Ithaca, NE (41.176 , $\left.-96.470^{\circ}\right)$

Assessment of preharvest sprouting: At physiological maturity, identified by the loss of chlorophyll from the peduncle, 20 heads were snapped per plot. Heads were dried overnight at $32.2^{\circ} \mathrm{C}$ and then stored at $-20^{\circ} \mathrm{C}$ until assayed. Two replications of 10 heads per plot were tested each harvest year. The total two-dimensional area $\left(\mathrm{cm}^{2}\right)$ of a 10-head sample was measured using a Li-Cor (Lincoln, NE) LI-3100C Leaf Area Meter. The heads then were placed for 7 days in a growth chamber set at a constant temperature of $21^{\circ} \mathrm{C}$, with a diurnal regime of 18-h light/6-h dark. Samples were subjected to misting six times daily for $20 \mathrm{~min}$ at 4-h intervals. After 7 days, the total area of each 10-head sample was again measured using the Li-Cor Leaf Area Meter. The change in area ( $\Delta$ area), resulting from shoot and root growth, was calculated as the difference in total area before and after misting. A tolerance score was then obtained by subtracting the value of $\Delta$ from 100. The value of 100 was chosen as it was exceeded only by the most susceptible cultivar 'Platte'. Numerically higher tolerance value scores therefore became indicative of greater tolerance to preharvest sprouting.

DNA marker analysis: DNA was extracted from experimental lines at the $\mathrm{F}_{4: 9}$ (2009-grown) generation. Leaf tissue from at least 12 individual plants per line was placed into a single well of a 1-ml 96-deep-well plate. The tissue was lyophilized for $48 \mathrm{~h}$ and ground to a fine powder using a 4-mm stainless steel bead with $4 \mathrm{~min}$ of agitation at 30 cycles per second on a mixer mill 400 (www.retsch.com). Total genomic DNA was extracted from the ground tissue using a sodium dodecyl sulphate (SDS)-based DNA extraction procedure as follows. Six-hundred millilitres of room temperature extraction buffer (EB) $[100 \mathrm{~mm}$ Tris- $\mathrm{HCl}$ $\mathrm{pH} \quad 8.0, \quad 50 \mathrm{~mm}$ EDTA $\mathrm{pH} \quad 8.0, \quad 1.25 \% \quad \mathrm{w} / \mathrm{v} \quad$ SDS, $2 \mathrm{~mm}$ Tris (2-carboxyethyl) phosphine hydrochloride (TCEP) and $2 \% \mathrm{w} / \mathrm{v}$ polyvinylpolypyrrolidone (PVPP)] was added to each ground sample. Samples with EB were shaken vigorously to break up the pellet and heated to $65^{\circ} \mathrm{C}$ in a water bath for $45-60 \mathrm{~min}$. The heated samples were again shaken vigorously, held at $-20^{\circ} \mathrm{C}$ for $10-15$ min after which $280 \mu \mathrm{l}$ of $7.5 \mathrm{~m}$ ammonium acetate was added. Samples were mixed by inversion, held at $4^{\circ} \mathrm{C}$ for $15 \mathrm{~min}$, and centrifuged at $6100 \mathrm{~g}$ for $15 \mathrm{~min}$ at $4^{\circ} \mathrm{C}$ to precipitate proteins and cell debris. The aqueous phase (approximately $400 \mu \mathrm{l}$ ) was transferred into a 1-ml 96-deep-well plate containing $400 \mu \mathrm{l}$ of cold isopropanol. Samples were mixed by inversion, held at $4^{\circ} \mathrm{C}$ for $30 \mathrm{~min}$ to overnight, and centrifuged at $6100 \mathrm{~g}$ for $30 \mathrm{~min}$ at $4^{\circ} \mathrm{C}$ to precipitate the DNA. The supernatant was discarded by smoothly inverting the plate. DNA pellets adhered to the bottom of the plate. DNA pellets were washed by adding $500 \mu \mathrm{l}$ of $70 \%$ ethanol, mixed by inversion and centrifuged at $6100 \mathrm{~g}$ for $15 \mathrm{~min}$ at $4^{\circ} \mathrm{C}$ to precipitate the DNA. The ethanol was discarded and the wash step repeated. Samples were air-dried at room temperature for 3-4 h to ensure ethanol removal. The DNA was resuspended in $500 \mu \mathrm{l}$ autoclaved $10 \mathrm{~mm}$ Tris $(\mathrm{pH} 8.0)$ with $0.003125 \%$ TritonX-100. Plates were then placed in a $65^{\circ} \mathrm{C}$ water bath for $30 \mathrm{~min}$, vortexed for $30 \mathrm{~s}$ and held at $4{ }^{\circ} \mathrm{C}$ overnight to allow the DNA to rehydrate. The final DNA concentrations (unadjusted) had an average concentration of approximately $20 \mathrm{ng} / \mu \mathrm{l}$.

Twelve previously described SSR primers (Röder et al. 1998, Pestsova et al. 2000, Gupta et al. 2002) known to be linked to putative QTL affecting preharvest sprouting (Liu et al. 2008, Munkvold et al. 2009) were selected for evaluation, and nine were found to be polymorphic within one or more populations. Primer pairs, sequences and loci detected are listed in Table 1. PCRs were conducted using a total volume of $13 \mu \mathrm{l}$ and contained three primers, a forward, M13 tailed primer at $200 \mathrm{~nm}$ and a reverse primer at $250 \mathrm{nM}$, and a $5^{\prime}$ dye-labelled M13 primer at $50 \mathrm{~nm}$. The PCRs also contained $1 \times$ ammonium sulphate PCR buffer (16 mm ammonium sulphate, $67 \mathrm{~mm}$ Tris-HCL, $\mathrm{pH} 8.8$ and $0.01 \%$ Tween-20), $2.5 \mathrm{~mm} \mathrm{MgCl}_{2}, 200 \mu \mathrm{m}$ each dNTP, $1 \mathrm{U}$ Taq, $0.3 \%$ 
Table 1: Primers used in DNA marker analysis

\begin{tabular}{|c|c|c|}
\hline Primers & DNA sequence & Locus/Chromosome \\
\hline GWM429F18 & ACGACGTTGTAAAACGACTTGTACATTAAGTTCCCATTA & Xgwm429, 2B \\
\hline GWM429R & TTTAAGGACCTACATGACAC & \\
\hline DUP398F18 & ACGACGTTGTAAAACGACCTGAGCCCTCTTTGCTATGC & Xdup398, 2B \\
\hline DUP398R & TCGGTGAGATTGAAAGGTCC & \\
\hline BARC54F18 & ACGACGTTGTAAAACGACGCGAACAGGAGGACAGAGGGCACGAGAG & Xbarc54, 2B \\
\hline BARC54R & GCGCTTTCCCACGTTCCATGTTTCT & \\
\hline BARC105F18 & ACGACGTTGTAAAACGACCAGGAAGAAAAGGAAAGCATGCGACAA & Xbarc105, 2B \\
\hline BARC105R & GCGGTGTGGCAATAATTACTTTTT & \\
\hline BARC12F18 & ACGACGTTGTAAAACGACCGACAGAGTGATCACCCAAATATAA & Xbarc12, 3A \\
\hline BARC12R & ATCGGTCTAATTGTCAATGTA & \\
\hline BARC57F18 & ACGACGTTGTAAAACGACGCGACCACCTCAGCCAACTTATTATGT & Xbarc57, 3A \\
\hline BARC57R & GCGGGGAGGCACATTCATAGGAGT & \\
\hline BARC321F18 & ACGACGTTGTAAAACGACTGCACTTCCCACAACACATC & Xbarc321, 3A \\
\hline BARC321R & TTGCCACGTAGGTGATTTATGA & \\
\hline GWM269F18 & ACGACGTTGTAAAACGACTGCATATAAACAGTCACACACCC & Xgwm269, 4A \\
\hline GWM269R & TTTGAGCTCCAAAGTGAGTTAGC & \\
\hline GWM397F18 & ACGACGTTGTAAAACGACTGTCATGGATTATTTGGTCGG & Xgwm397, 4A \\
\hline GWM397R & CTGCACTCTCGGTATACCAGC & \\
\hline
\end{tabular}

Tween-20 and $3 \mu \mathrm{l}$ of template DNA at a concentration of $25 \mathrm{ng} / \mu \mathrm{l}$. PCRs were performed using a touch-down profile as follows: $95^{\circ} \mathrm{C}$ for $5 \mathrm{~min}$; then five cycles of $96^{\circ} \mathrm{C}$ for $1 \mathrm{~min}, 68^{\circ} \mathrm{C}$ for $3 \mathrm{~min}\left(-2^{\circ} \mathrm{C} /\right.$ cycle $)$, $72^{\circ} \mathrm{C}$ for $1 \mathrm{~min}$; then five cycles of $96^{\circ} \mathrm{C}$ for $1 \mathrm{~min}, 58^{\circ} \mathrm{C}$ for $2 \mathrm{~min}$ $\left(-2^{\circ} \mathrm{C} /\right.$ cycle), $72^{\circ} \mathrm{C}$ for $1 \mathrm{~min}$; then 40 cycles of $96^{\circ} \mathrm{C}$ for $20 \mathrm{~s}, 50^{\circ} \mathrm{C}$ for $20 \mathrm{~s}, 72^{\circ} \mathrm{C}$ for $30 \mathrm{~s}$; then a final cycle of $72^{\circ} \mathrm{C}$ for $5 \mathrm{~min}$ and $10^{\circ} \mathrm{C}$ for $5 \mathrm{~min}$. Fluorescent dye-labelled PCR products were separated and detected using an ABI Prism 3730 (www.appliedbiosystems.com) sequencer with a 50-cm capillary. Peak data were extracted from ABI files using GeneMARKer version 1.6 (SoftGenetics.com).

Statistical analysis: All statistical computations were conducted for this study using PC SAS software version 9.2 (SAS Institute Inc., Cary, NC, USA). Analysis of variance (Proc GLM) was conducted to evaluate sources of variation for sprouting tolerance within each population. Main effects included 'year' and 'entry' and heading date was included in the models as a covariate.

For each marker evaluated, lines were characterized by selecting the most reproducible and consistent PCR products observed. Only entries homozygous and homogeneous for each selected marker, and based on unambiguous PCR results, were included in the statistical analyses. Analysis of variance again was used to evaluate the relationships between marker genotypes and sprouting tolerance. Separate analyses were conducted for each marked locus within each population. For these analyses, the main effects 'year' and 'locus' and the interaction of locus*year were evaluated. For those loci demonstrating significant differences by ANOVA, mean sprouting tolerances were calculated separately for each locus within each population. Finally, when sample sizes were adequate, the effects of alleles at two independent loci were evaluated by ANOVA, again separately for each population.

\section{Results}

Sprouting tolerance indices (Table 2) of control cultivars ranged from a high of 70.8 in the hard red winter wheat 'Camelot' to a low of -4.2 in the hard white winter wheat 'Platte'. In general, hard red winter wheat controls had higher tolerance scores than the hard white controls; however, exceptions existed in both classes. The hard white winter wheats 'Nuplains' and 'Trego' displayed tolerance scores equal to or exceeding those of some hard red wheats. The hard red wheat 'Pronghorn' was characterized by a tolerance score equal to those of known susceptible hard white wheats 'Antelope' and 'Arrowsmith'.

Significant differences in tolerance scores were observed among entries in all four populations (Table 3). Significant variation asso-
Table 2: Sprouting tolerance of check cultivars and parents

\begin{tabular}{llcr}
\hline Entry & Market class & $\begin{array}{c}\text { Tolerance } \\
\text { score (mean) }\end{array}$ & Std. err \\
\hline Camelot & HRW & 70.8 & 5.2 \\
Wesley & HRW & 67.6 & 2.3 \\
Jagalene & HRW & 66.9 & 3.5 \\
Nuplains & HWW & 53.7 & 7.7 \\
Trego & HWW & 50.7 & 6.8 \\
NW98S061 & HWW & 49.5 & 7.2 \\
Overland & HRW & 47.3 & 4.9 \\
Arapahoe & HRW & 43.9 & 5.6 \\
NW97S218 & HWW & 35.7 & 13.3 \\
Rio Blanco & HWW & 31.9 & 3.6 \\
Anton & HWW & 21.1 & 4.9 \\
NW97S186 & HWW & 16.7 & 8.6 \\
Pronghorn & HRW & 14.7 & 6.1 \\
Arrowsmith & HWW & 11.6 & 4.3 \\
Antelope & HWW & 4.8 & 3.6 \\
Platte & HWW & -4.2 & 4.9 \\
\hline
\end{tabular}

HRW, hard red winter wheat; HWW, hard white winter wheat.

ciated with cultural environments (main effect 'year') was observed in three of the four populations. Heading date, when evaluated as a covariate, had no effect on observed tolerance scores in any of the four populations. Thus, both genetic factors and environments contributed to observed variation in tolerance scores. Mean tolerance scores (Table 3) in the four populations were similar to each other, ranging from 21.1 to 27.2 , and were similar to that of the susceptible hard white winter wheat 'Anton'. Observed ranges in all four populations were larger than the range observed among the control cultivars, ranging from highly negative minimum scores to maximum values equal to those of the most tolerant hard red wheat cultivars tested.

Mean values of each observed genotype at each locus demonstrating significant differences by ANOVA were calculated for the experimental lines within each of the four breeding populations. Loci on chromosome $3 \mathrm{~A}$ were associated with mean differences between genotypes in three of the four populations, and across populations (Table 5). In the present experiments (Tables 4 and 5), significant differences in tolerance also were associated with marker polymorphisms on chromosome $2 \mathrm{~B}$ in three populations: Nuplains/Arrowsmith, NW98S061/Rio Blanco and NW97S186/ Rio Blanco. Based on pedigree analysis, 'Nuplains' likely carries the Rio Blanco-derived 3AS gene(s) for tolerance to preharvest 
Table 3: Analysis of variance of tolerance to preharvest sprouting in four populations of hard white winter wheats grown at Mead, NE USA

\begin{tabular}{|c|c|c|c|c|c|c|c|c|c|c|}
\hline \multirow[b]{2}{*}{ Population } & \multicolumn{5}{|c|}{ Tolerance score } & \multicolumn{5}{|c|}{ Analysis of variance } \\
\hline & Mean & $\mathrm{n}$ & Std. err & Min & Max & Source & df & Mean square & $F$ & $\mathrm{P}$ \\
\hline \multirow[t]{3}{*}{ Nuplains/Arrowsmith } & \multirow[t]{3}{*}{26.5} & \multirow[t]{3}{*}{95} & \multirow[t]{3}{*}{2.5} & \multirow{3}{*}{-33.7} & \multirow[t]{3}{*}{79.7} & Year & 3 & 3104 & 5.50 & 0.0011 \\
\hline & & & & & & Entry & 94 & 1723 & 3.05 & $<0.0001$ \\
\hline & & & & & & HDT & 25 & 305 & 0.54 & 0.9651 \\
\hline \multirow[t]{3}{*}{ NW98S061/Rio Blanco } & \multirow[t]{3}{*}{26.5} & \multirow[t]{3}{*}{92} & \multirow[t]{3}{*}{2.1} & \multirow[t]{3}{*}{-13.7} & \multirow[t]{3}{*}{76.9} & Year & 3 & 11257 & 20.3 & $<0.0001$ \\
\hline & & & & & & Entry & 91 & 1280 & 2.31 & $<0.0001$ \\
\hline & & & & & & HDT & 19 & 750 & 1.35 & 0.1529 \\
\hline \multirow[t]{3}{*}{ NW97S186/Rio Blanco } & \multirow[t]{3}{*}{21.1} & \multirow[t]{3}{*}{187} & \multirow[t]{3}{*}{1.6} & \multirow[t]{3}{*}{-52.8} & \multirow[t]{3}{*}{63.7} & Year & 3 & 3710 & 4.91 & 0.0023 \\
\hline & & & & & & Entry & 186 & 1521 & 2.01 & $<0.0001$ \\
\hline & & & & & & HDT & 23 & 916 & 1.21 & 0.2268 \\
\hline \multirow[t]{3}{*}{ Rio Blanco/NW97S218 } & \multirow[t]{3}{*}{27.2} & \multirow[t]{3}{*}{95} & \multirow[t]{3}{*}{2.0} & \multirow[t]{3}{*}{-20.9} & \multirow[t]{3}{*}{75.5} & Year & 3 & 207 & 0.31 & 0.8178 \\
\hline & & & & & & Entry & 94 & 1275 & 1.91 & $<0.0001$ \\
\hline & & & & & & HDT & 21 & 499 & 0.75 & 0.7806 \\
\hline
\end{tabular}

Table 4: Mean squares from analysis of variance of markers for tolerance to preharvest sprouting in four populations of hard white winter wheat grown at Mead, NE, 2007-2010

\begin{tabular}{|c|c|c|c|c|c|c|c|}
\hline \multirow[b]{2}{*}{ Population } & \multirow[b]{2}{*}{ Locus } & \multirow[b]{2}{*}{ Chromosome } & \multirow[b]{2}{*}{ Polymorphic } & \multicolumn{4}{|c|}{ Mean squares } \\
\hline & & & & Year & Locus & Year*Locus & Error \\
\hline \multirow[t]{9}{*}{ Nuplains/Arrowsmith } & Xgwm429 & $2 \mathrm{~B}$ & + & $2178.04 *$ & 481.93 & 899.15 & 873.11 \\
\hline & Xdup398 & $2 \mathrm{~B}$ & + & $3065.77 *$ & $10397.25^{*}$ & 308.35 & 1000.41 \\
\hline & Xbarc54 & $2 B$ & + & $2575.73 *$ & $10989.43^{*}$ & 784.53 & 773.96 \\
\hline & Xbarc105 & $2 \mathrm{~B}$ & - & & & & \\
\hline & Xbarc12 & $3 \mathrm{~A}$ & + & $2029.44 *$ & $63605.11^{*}$ & 708.09 & 765.86 \\
\hline & Xbarc57 & $3 \mathrm{~A}$ & + & $7193.39 *$ & 78307.86* & 889.35 & 859.74 \\
\hline & Xbarc321 & $3 \mathrm{~A}$ & + & $3592.67 *$ & $29658.65^{*}$ & 600.25 & 857.98 \\
\hline & Xgwm269 & $4 \mathrm{~A}$ & + & 1875.12 & $46803.62^{*}$ & 272.99 & 842.63 \\
\hline & Xgwm397 & $4 B$ & + & $3232.68^{*}$ & $19155.32 *$ & 647.13 & 903.76 \\
\hline \multirow[t]{9}{*}{ NW98S061/Rio Blanco } & Xgwm429 & $2 \mathrm{~B}$ & + & 660.74 & 48.28 & 514.35 & 788.74 \\
\hline & Xdup398 & $2 \mathrm{~B}$ & + & $8052.52 *$ & $6490.94 *$ & 799.27 & 802.27 \\
\hline & Xbarc54 & $2 \mathrm{~B}$ & - & & & & \\
\hline & Xbarc105 & $2 \mathrm{~B}$ & + & $5242.85^{*}$ & $7710.75^{*}$ & 350.35 & 707.59 \\
\hline & Xbarc12 & $3 \mathrm{~A}$ & + & $7139.62 *$ & 1176.91 & 189.36 & 769.34 \\
\hline & Xbarc57 & $3 \mathrm{~A}$ & + & $9187.07 *$ & 141.65 & 350.76 & 815.87 \\
\hline & Xbarc321 & $3 \mathrm{~A}$ & + & $7784.23 *$ & 218.76 & 433.36 & 798.74 \\
\hline & Xgwm269 & $4 \mathrm{~A}$ & + & $20361.11 *$ & 479.09 & 155.03 & 775.51 \\
\hline & Xgwm397 & $4 \mathrm{~A}$ & + & $8444.93 *$ & 972.25 & 456.05 & 786.52 \\
\hline \multirow[t]{9}{*}{ NW97S186/Rio Blanco } & Xgwm429 & $2 \mathrm{~B}$ & - & & & & \\
\hline & Xdup398 & $2 \mathrm{~B}$ & + & $3623.16^{*}$ & 1320.33 & 887.25 & 983.33 \\
\hline & Xbarc54 & 2B & + & 2336.83 & 424.33 & 1619.03 & 948.19 \\
\hline & Xbarc105 & $2 \mathrm{~B}$ & + & $3955.81^{*}$ & $5434.04 *$ & 2748.18 & 960.12 \\
\hline & Xbarc12 & $3 \mathrm{~A}$ & + & $4275.36^{*}$ & $10318.46^{*}$ & 675.28 & 961.78 \\
\hline & Xbarc57 & $3 \mathrm{~A}$ & + & $4640.19 *$ & $8466.13^{*}$ & 1617.13 & 964.64 \\
\hline & Xbarc321 & $3 \mathrm{~A}$ & + & $2729.69 *$ & $6107.33^{*}$ & 1529.62 & 935.62 \\
\hline & Xgwm269 & $4 \mathrm{~A}$ & + & $3285.13 *$ & 3003.24 & 466.51 & 935.74 \\
\hline & Xgwm397 & $4 \mathrm{~A}$ & + & $3905.25^{*}$ & 2270.59 & 691.08 & 950.98 \\
\hline \multirow[t]{9}{*}{ Rio Blanco/NW97S218 } & Xgwm429 & $2 \mathrm{~B}$ & + & 930.61 & 1501.93 & 381.59 & 841.41 \\
\hline & Xdup398 & $2 \mathrm{~B}$ & + & 326.11 & 14.41 & 574.54 & 834.96 \\
\hline & Xbarc054 & $2 \mathrm{~B}$ & + & 104.79 & 30.67 & 272.86 & 819.33 \\
\hline & Xbarc105 & $2 \mathrm{~B}$ & + & 120.96 & 547.53 & 725.73 & 834.75 \\
\hline & Xbarc12 & $3 \mathrm{~A}$ & + & 1057.77 & $7464.62 *$ & 122.35 & 813.99 \\
\hline & Xbarc57 & $3 \mathrm{~A}$ & + & 373.59 & $17729.07 *$ & 327.81 & 771.51 \\
\hline & Xbarc321 & $3 \mathrm{~A}$ & - & & & & \\
\hline & Xgwm269 & $4 \mathrm{~A}$ & + & 760.18 & 1415.15 & 559.03 & 845.96 \\
\hline & Xgwm397 & $4 \mathrm{~A}$ & + & 525.22 & 335.23 & 147.93 & 818.62 \\
\hline
\end{tabular}

*Significant effects or differences observed at $\mathrm{P}=0.05$ level.

sprouting (see Materials and Methods). In NW98S061/Rio Blanco, loci on 2B were the only ones identified as having significant effects on tolerance. In Nuplains/Arrowsmith, significant effects associated with the loci Xdup398 and Xbarc54 (Table 5) indicated the detection of QPhs.pseru-2B1. In NW98S061/Rio Blanco, significant differences were noted for genotypes at Xdup398 and Xbarc105, indicating the presence of both QPhs.pseru-2B1 and QPhs.pseru-2B2. In NW97S186/Rio
Blanco, only the minor QTL, QPhs.pseru-2B2, was detected. In the present study, significant differences were detected for polymorphic loci on chromosome 4A only in Nuplains/Arrowsmith (Tables 4 and 5).

While significant differences in mean tolerances of genotypes were observed in all populations, it was clear that variability was observed among lines with specific genotypes. Examples are shown in Figs 1 and 2. While the mean tolerance of lines with 
Table 5: Mean sprouting tolerance scores ${ }^{1}$ for lines with respective marker alleles in four populations of hard white winter wheat grown at Mead, NE USA, 2007-2010

\begin{tabular}{|c|c|c|c|c|c|c|c|}
\hline Population & Locus & Chromosome & Genotype $^{2}$ & No lines ${ }^{3}$ & Mean & Std. err & Effect \\
\hline \multirow[t]{14}{*}{ Nuplains/Arrowsmith } & \multirow[t]{2}{*}{ Xdup398 } & \multirow[t]{2}{*}{$2 \mathrm{~B}$} & $203 \mathrm{NP}$ & 47 & 29.2 & 2.1 & $\mathrm{~T}$ \\
\hline & & & $215 \mathrm{AR}$ & 24 & 16.6 & 3.8 & $\mathrm{~S}$ \\
\hline & \multirow[t]{2}{*}{ Xbarc54 } & \multirow[t]{2}{*}{$2 \mathrm{~B}$} & 178AR & 28 & 21.3 & 2.9 & $\mathrm{~S}$ \\
\hline & & & $182 \mathrm{NP}$ & 40 & 34.1 & 2.1 & $\mathrm{~T}$ \\
\hline & \multirow[t]{2}{*}{ Xbarc12 } & \multirow[t]{2}{*}{$3 \mathrm{~A}$} & 200AR & 38 & 9.4 & 2.4 & $\mathrm{~S}$ \\
\hline & & & $219 \mathrm{NP}$ & 31 & 40.1 & 2.3 & $\mathrm{~T}$ \\
\hline & \multirow[t]{2}{*}{ Xbarc57 } & \multirow[t]{2}{*}{$3 \mathrm{~A}$} & 261AR & 40 & 10.7 & 2.5 & $\mathrm{~S}$ \\
\hline & & & $280 \mathrm{NP}$ & 38 & 39.1 & 2.0 & $\mathrm{~T}$ \\
\hline & \multirow[t]{2}{*}{ Xbarc321 } & \multirow[t]{2}{*}{$3 \mathrm{~A}$} & $185 \mathrm{NP}$ & 58 & 31.9 & 1.9 & $\mathrm{~T}$ \\
\hline & & & 198AR & 29 & 12.2 & 3.0 & $\mathrm{~S}$ \\
\hline & \multirow[t]{2}{*}{ Xgwm269 } & \multirow[t]{2}{*}{$4 \mathrm{~A}$} & 140AR & 59 & 17.2 & 2.0 & $\mathrm{~S}$ \\
\hline & & & $148 \mathrm{NP}$ & 25 & 43.1 & 2.6 & $\mathrm{~T}$ \\
\hline & \multirow[t]{2}{*}{ Xgwm397 } & \multirow[t]{2}{*}{$4 \mathrm{~A}$} & $189 \mathrm{NP}$ & 53 & 31.4 & 2.1 & $\mathrm{~T}$ \\
\hline & & & 197AR & 36 & 16.4 & 2.6 & $\mathrm{~S}$ \\
\hline \multirow[t]{4}{*}{ NW98S061/Rio Blanco } & \multirow[t]{2}{*}{ Xdup398 } & \multirow[t]{2}{*}{$2 \mathrm{~B}$} & 203N61 & 39 & 20.3 & 2.6 & $\mathrm{~S}$ \\
\hline & & & $215 \mathrm{RB}$ & 33 & 29.9 & 2.3 & $\mathrm{~T}$ \\
\hline & \multirow[t]{2}{*}{ Xbarc105 } & \multirow[t]{2}{*}{ 2B } & $147 \mathrm{RB}$ & 35 & 31.2 & 2.1 & $\mathrm{~T}$ \\
\hline & & & $158 \mathrm{~N} 61$ & 35 & 20.6 & 2.5 & $\mathrm{~S}$ \\
\hline \multirow[t]{8}{*}{ NW97S186/Rio Blanco } & \multirow[t]{2}{*}{ Xbarc105 } & \multirow[t]{2}{*}{$2 \mathrm{~B}$} & $147 \mathrm{RB}$ & 81 & 23.6 & 1.7 & $\mathrm{~T}$ \\
\hline & & & $170 \mathrm{~N} 186$ & 61 & 17.4 & 2.1 & $\mathrm{~S}$ \\
\hline & \multirow[t]{2}{*}{ Xbarc12 } & \multirow[t]{2}{*}{$3 \mathrm{~A}$} & $200 \mathrm{~N} 186$ & 71 & 16.7 & 2.0 & $\mathrm{~S}$ \\
\hline & & & 219RB & 69 & 25.3 & 1.7 & $\mathrm{~T}$ \\
\hline & \multirow[t]{2}{*}{ Xbarc57 } & \multirow[t]{2}{*}{$3 \mathrm{~A}$} & $252 \mathrm{~N} 186$ & 62 & 17.2 & 2.2 & $\mathrm{~S}$ \\
\hline & & & 280RB & 89 & 24.8 & 1.5 & $\mathrm{~T}$ \\
\hline & \multirow[t]{2}{*}{ Xbarc321 } & $3 \mathrm{~A}$ & $185 \mathrm{RB}$ & 117 & 23.2 & 1.4 & $\mathrm{~T}$ \\
\hline & & & $197 N 186$ & 44 & 16.3 & 2.6 & $\mathrm{~S}$ \\
\hline Rio Blanco/NW97S218 & Xbarc12 & $3 \mathrm{~A}$ & $200 \mathrm{~N} 218$ & 34 & 20.1 & 2.4 & $\mathrm{~S}$ \\
\hline & & & 219RB & 30 & 31.0 & 2.6 & $\mathrm{~T}$ \\
\hline & Xbarc57 & $3 \mathrm{~A}$ & $252 \mathrm{~N} 218$ & 41 & 18.6 & 2.2 & $\mathrm{~S}$ \\
\hline & & & 280RB & 41 & 33.2 & 2.1 & $\mathrm{~T}$ \\
\hline Across populations ${ }^{4}$ & Xbarc57 & $3 \mathrm{~A}$ & 252 or 261 & 143 & 15.9 & 1.3 & $\mathrm{~S}$ \\
\hline & & & 280 & 166 & 30.1 & 2.3 & $\mathrm{~T}$ \\
\hline & Xbarc12 & $3 \mathrm{~A}$ & 200 & 142 & 15.6 & 1.3 & $\mathrm{~S}$ \\
\hline & & & 219 & 129 & 30.2 & 1.2 & $\mathrm{~T}$ \\
\hline
\end{tabular}

$\mathrm{T}=$ allele associated with greater tolerance to preharvest sprouting; $\mathrm{S}=$ allele associated with greater susceptibility.

${ }^{1}$ Means are presented only for those markers with significant $(\mathrm{P}=0.05)$ differences indicated by ANOVA.

${ }^{2}$ Genotypes are indicated by size of PCR products in bp plus a parental designation. Parental designations are: NP = Nuplains, AR = Arrowsmith, N61 = NW98S061, RB = Rio Blanco, N186 = NW98S186, N218 = NW97S218.

${ }^{3}$ Only homogeneous, homozygous lines included.

${ }^{4}$ Includes populations in which Xbarc12 or Xbarc57 alleles were significantly different by ANOvA.

the 'tolerant' chromosome 3A QTL linked to Xbarc12 was higher in three of the four populations (Fig. 1), overlap occurred between the genotypic classes, although less overlap was evident in the Nuplains/Arrowsmith population than in the additional populations. Similar results were observed for the chromosome 2B marker Xbarc105 in NW98S061/Rio Blanco (Fig. 2). In both cases, results clearly demonstrate that while major genes conditioning tolerance to preharvest sprouting have been identified in these populations, in every case additional, unidentified minor and perhaps major genes also influence the trait.

In an attempt to further define the utility of marker-assisted selection for tolerance to preharvest sprouting, all possible combinations of unlinked markers were evaluated using a two-gene model (Tables 6 and 7). These analyses were conducted only in Nuplains/Arrowsmith and NW97S186/Rio Blanco, the two populations in which significant differences were observed in mean tolerance scores for at least two unlinked markers. Within $\mathrm{Nu}-$ plains/Arrowsmith (Table 6), mean tolerance scores of all TT (two putative unlinked alleles contributing to greater tolerance) classes were significantly greater (and generally four times as large) than those of the SS (two putative susceptible alleles) classes. Tolerance of the TS and ST classes (one putative tolerant allele and one susceptible allele) generally was intermediate, indicating additive gene action. While the presence of one toler- ant allele likely would afford protection against preharvest sprouting, the presence of two affords the greatest prophylactic effect. The same observations were not evident in NW97S186/ Rio Blanco (Table 7). Again, the TT class was always significantly greater in mean tolerance than the SS class. However, the TS and ST classes were never significantly different from the TT classes, and additive gene action was not evident. In $\mathrm{Nu}-$ plains/Arrowsmith, additive action was observed between marker alleles linked to QPhs.pseru-2B1 and loci on chromosomes 3A and 4A (Table 6). In NW97S186/Rio Blanco, QPhs.pseru-2B2 was detected (marked by Xbarc105) and demonstrated no additive gene action with QPhs.pseru-3AS.

\section{Discussion}

The sprouting tolerance assay reported herein readily separated known tolerant cultivars such as 'Jagalene' (Ibrahim et al. 2008) from known susceptible cultivars such as 'Pronghorn' (http://cropwatch.unl.edu/web/wheat/pronghorn). Using the assay to evaluate multiple field trials found significant variation associated with the main effect 'year' for nearly all polymorphic markers in the Nuplains/Arrowsmith, NW98S061/Rio Blanco and NW97S186/ Rio Blanco-derived populations. However, in the Rio Blanco/ NW97S218-derived population, no significant variation was asso- 

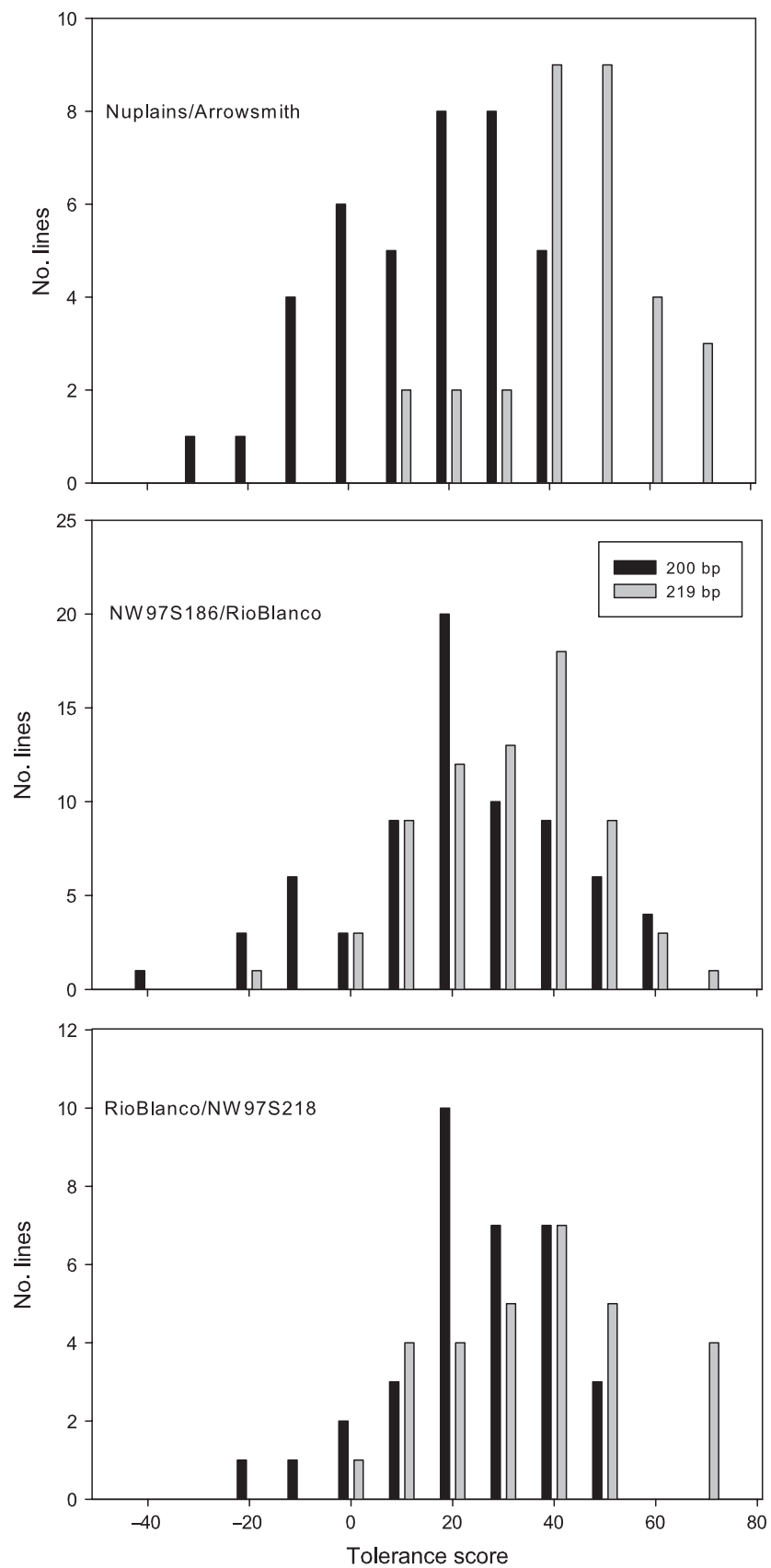

Fig. 1: Histograms of pre-harvest tolerance scores of lines with alternate alleles at the marker locus Xbarc12 (chromosome 3A) in three breeding populations of hard white winter wheat

ciated with 'year' for any allelic contrast (Table 4). No significant interaction of year-by-locus was observed in any of the four populations. Biddulph et al. (2008) obtained similar results, noting the $\mathrm{G}$ by $\mathrm{E}$ interaction did not account for a large proportion of the variation ... in sprouting tolerance (measured by falling number after rainfall) or change the relative rankings of preharvest sprouting tolerance'. Similarly, Kulwal et al. (2004), using a QTL marker approach, found that the largest percentage $(76.68 \%)$ of the total phenotypic variation in sprouting tolerance was due to genetic factors, with environment explaining an additional $28.73 \%$. QTL-by-environment interaction, in contrast, explained only a modest $(3.24 \%)$ portion of the observed variation. Rasul et al. (2012), using a diverse set of red- and white-seeded spring wheats, noted that genotypic variances associated with tolerance to

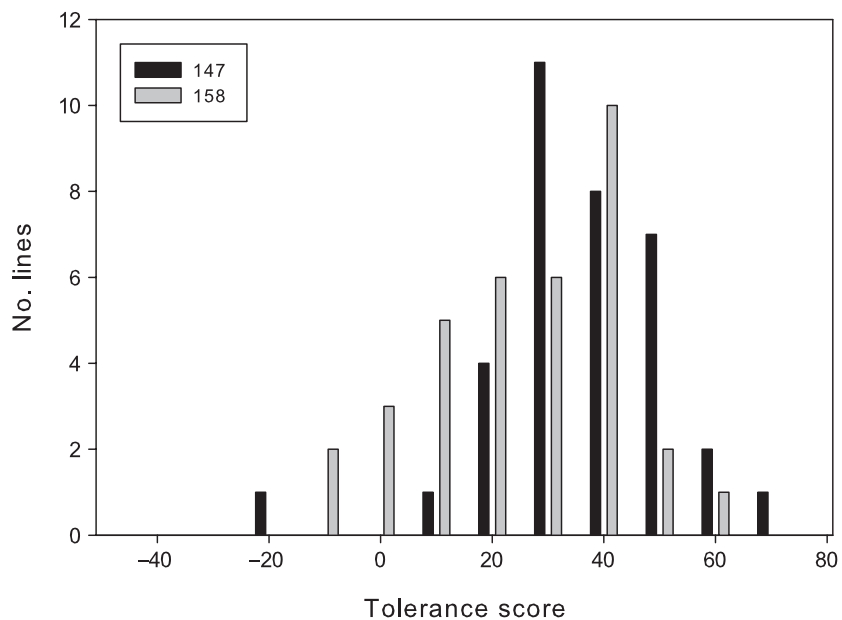

Fig. 2: Histograms of tolerance scores of lines with alternate alleles at the marker locus (Xbarc105, chromosome 2B) in a breeding population of hard white winter wheat derived from NW98S061/RioBlanco

preharvest sprouting exceeded genotype-by-environment interaction variances. These results all suggest that while variation in environmental factors (year-to-year) can modulate the effects of sprouting tolerance alleles, these effects likely are predictable, and genotypic rankings should remain constant even under fluctuating environments. As Rasul et al. (2012) suggested, genotypic-based selection schemes should result in enhanced tolerance to preharvest sprouting, regardless of environmental factors.

Liu et al. (2008) reported that SSR marker Xbarc321 had the largest effect on preharvest sprouting resistance in four experiments and was the closest marker to QPhs.pseru-3AS. In the present investigation, Xbarc321 was significantly associated with mean differences in tolerance in two populations (Nuplains/Arrowsmith and NW97S186/Rio Blanco), as were the linked marker loci Xbarc12 and Xbarc57. Xbarc321 was not polymorphic in Rio Blanco/NW97S218, but the linked loci Xbarc12 and Xbarc57 were, and also were significantly associated with tolerance. The present investigation confirms the contribution of QPhs.pseru-3AS to tolerance to preharvest sprouting, and the utility of using linked DNA markers as a surrogate for direct phenotypic selection. Across three populations, PCR products marking tolerant alleles were identical; this instils further confidence in using marker-assisted selection for the trait. In addition, the presence of additional QTLs on chromosomes 2B and 4A was confirmed. These genes may be pyramided with QPhs.pser$u-3 A S$ to develop lines with even greater tolerances, as demonstrated in the two-locus analysis in Nuplains/Arrowsmith, or selected and fixed in populations in which markers for QPhs.pseru-3AS either are not segregating or have no effect.

In every observed case of significant differences associated with allelic variation at marker loci (Table 5), the nature of the alleles was the same. In other words, the size of the PCR product associated with enhanced tolerance was identical in the studied populations. Difficult to explain, however, was the lack of observed effects of loci on 3A in the NW98S061/Rio Blanco population, even though lines in this population demonstrated the same polymorphic PCR products at marker loci as those observed in the remaining populations. In this population, however, both QPhs.pseru-2B1 and QPhs.pseru-2B2 were detected, and significant effects were demonstrated for each. Liu et al. (2008) attributed more of the observed variation in tolerance to QPhs.pseru-2B1 than to QPhs.pseru-2B2. Taken together, the results of Liu et al. (2008) and the present investigation suggest 
Table 6: Mean sprouting tolerance of genotypes identified by two independent loci within Nuplains/Arrowsmith

\begin{tabular}{|c|c|c|c|c|c|c|c|}
\hline Locus 1 & Chromosome & $\begin{array}{c}\text { Putative } \\
\text { phenotype }^{1}\end{array}$ & Locus 2 & Chromosome & $\begin{array}{c}\text { Putative } \\
\text { phenotype }^{1}\end{array}$ & $\begin{array}{l}\text { No. } \\
\text { lines }\end{array}$ & $\begin{array}{c}\text { Tolerance } \\
\text { (mean) }\end{array}$ \\
\hline \multirow[t]{4}{*}{ Xdup398 } & \multirow[t]{4}{*}{$2 \mathrm{~B}$} & $\mathrm{~T}$ & \multirow[t]{4}{*}{ Xbarc12 } & \multirow[t]{4}{*}{$3 \mathrm{~A}$} & $\mathrm{~T}$ & 21 & $40.8 \mathrm{a}$ \\
\hline & & $\mathrm{T}$ & & & $\mathrm{S}$ & 15 & $6.9 \mathrm{c}$ \\
\hline & & S & & & $\mathrm{T}$ & 6 & $27.8 \mathrm{~b}$ \\
\hline & & $\mathrm{S}$ & & & $\mathrm{S}$ & 14 & $6.0 \mathrm{c}$ \\
\hline \multirow[t]{4}{*}{ Xdup398 } & \multirow[t]{4}{*}{$2 \mathrm{~B}$} & $\mathrm{~T}$ & \multirow[t]{4}{*}{ Xbarc57 } & \multirow[t]{4}{*}{$3 \mathrm{~A}$} & $\mathrm{~T}$ & 25 & $39.3 \mathrm{a}$ \\
\hline & & $\mathrm{T}$ & & & $\mathrm{S}$ & 14 & $10.8 \mathrm{~b}$ \\
\hline & & $\mathrm{S}$ & & & $\mathrm{T}$ & 8 & $30.5 \mathrm{a}$ \\
\hline & & $\mathrm{S}$ & & & $\mathrm{S}$ & 15 & $5.6 \mathrm{~b}$ \\
\hline \multirow{4}{*}{ Xdup398 } & \multirow{4}{*}{$2 \mathrm{~B}$} & $\mathrm{~T}$ & \multirow{4}{*}{ Xbarc321 } & \multirow[t]{4}{*}{$3 \mathrm{~A}$} & $\mathrm{~T}$ & 37 & $33.3 \mathrm{a}$ \\
\hline & & $\mathrm{T}$ & & & $\mathrm{S}$ & 9 & $9.9 b$ \\
\hline & & S & & & $\mathrm{T}$ & 12 & $26.2 \mathrm{a}$ \\
\hline & & $\mathrm{S}$ & & & $\mathrm{S}$ & 11 & $7.7 \mathrm{~b}$ \\
\hline \multirow[t]{4}{*}{ Xdup398 } & \multirow[t]{4}{*}{$2 \mathrm{~B}$} & $\mathrm{~T}$ & \multirow[t]{4}{*}{ Xgwm269 } & $4 \mathrm{~A}$ & $\mathrm{~T}$ & 15 & $43.7 \mathrm{a}$ \\
\hline & & $\mathrm{T}$ & & & $\mathrm{S}$ & 29 & $19.9 \mathrm{~b}$ \\
\hline & & $\mathrm{S}$ & & & $\mathrm{T}$ & 6 & $39.7 \mathrm{a}$ \\
\hline & & $\mathrm{S}$ & & & S & 18 & $8.8 \mathrm{~b}$ \\
\hline Xdup398 & $2 \mathrm{~B}$ & $\mathrm{~T}$ & Xgwm397 & $4 \mathrm{~A}$ & $\mathrm{~T}$ & 26 & $38.4 \mathrm{a}$ \\
\hline & & $\mathrm{T}$ & & & S & 21 & $18.0 \mathrm{~b}$ \\
\hline & & $\mathrm{S}$ & & & $\mathrm{T}$ & 12 & $20.2 \mathrm{~b}$ \\
\hline & & $\mathrm{S}$ & & & $\mathrm{S}$ & 11 & $10.2 b$ \\
\hline Xbarc54 & $2 \mathrm{~B}$ & $\mathrm{~T}$ & Xbarc12 & $3 \mathrm{~A}$ & $\mathrm{~T}$ & 23 & $39.0 \mathrm{a}$ \\
\hline & & $\mathrm{T}$ & & & $\mathrm{S}$ & 5 & $22.1 \mathrm{~b}$ \\
\hline & & $\mathrm{S}$ & & & $\mathrm{T}$ & 4 & $39.4 \mathrm{a}$ \\
\hline & & $\mathrm{S}$ & & & $\mathrm{S}$ & 18 & $11.1 \mathrm{~b}$ \\
\hline Xbarc54 & $2 \mathrm{~B}$ & $\mathrm{~T}$ & Xbarc321 & $3 \mathrm{~A}$ & $\mathrm{~T}$ & 30 & $36.0 \mathrm{a}$ \\
\hline & & $\mathrm{T}$ & & & $\mathrm{S}$ & 8 & $24.1 \mathrm{~b}$ \\
\hline & & $\mathrm{S}$ & & & $\mathrm{T}$ & 15 & $31.3 \mathrm{ab}$ \\
\hline & & $\mathrm{S}$ & & & $\mathrm{S}$ & 12 & $10.9 \mathrm{c}$ \\
\hline Xbarc54 & $2 \mathrm{~B}$ & $\mathrm{~T}$ & Xgwm269 & $4 \mathrm{~A}$ & $\mathrm{~T}$ & 19 & $43.5 \mathrm{a}$ \\
\hline & & $\mathrm{T}$ & & & $\mathrm{S}$ & 17 & $22.7 \mathrm{bc}$ \\
\hline & & $\mathrm{S}$ & & & $\mathrm{T}$ & 3 & 35.9ab \\
\hline & & $\mathrm{S}$ & & & $\mathrm{S}$ & 24 & $19.3 c$ \\
\hline Xbarc54 & $2 \mathrm{~B}$ & $\mathrm{~T}$ & Xgwm397 & $4 \mathrm{~A}$ & $\mathrm{~T}$ & 24 & $39.9 a$ \\
\hline & & $\mathrm{T}$ & & & $\mathrm{S}$ & 15 & $24.4 \mathrm{~b}$ \\
\hline & & $\mathrm{S}$ & & & $\mathrm{T}$ & 15 & $30.8 \mathrm{ab}$ \\
\hline & & $\mathrm{S}$ & & & $\mathrm{S}$ & 13 & $10.2 \mathrm{c}$ \\
\hline Xbarc12 & $3 \mathrm{~A}$ & $\mathrm{~T}$ & Xgwm269 & $4 \mathrm{~A}$ & $\mathrm{~T}$ & 17 & $44.5 \mathrm{a}$ \\
\hline & & $\mathrm{T}$ & & & S & 11 & $32.1 \mathrm{ab}$ \\
\hline & & $\mathrm{S}$ & & & $\mathrm{T}$ & 2 & $16.0 \mathrm{bc}$ \\
\hline & & $\mathrm{S}$ & & & $\mathrm{S}$ & 35 & $8.6 \mathrm{c}$ \\
\hline Xbarc12 & $3 \mathrm{~A}$ & $\mathrm{~T}$ & Xgwm397 & $4 \mathrm{~A}$ & $\mathrm{~T}$ & 21 & $44.7 \mathrm{a}$ \\
\hline & & $\mathrm{T}$ & & & $\mathrm{S}$ & 9 & $29.4 b$ \\
\hline & & S & & & $\mathrm{T}$ & 19 & $11.2 \mathrm{c}$ \\
\hline & & $\mathrm{S}$ & & & $\mathrm{S}$ & 19 & $7.5 \mathrm{c}$ \\
\hline Xbarc57 & $3 \mathrm{~A}$ & $\mathrm{~T}$ & Xgwm269 & $4 \mathrm{~A}$ & $\mathrm{~T}$ & 19 & $43.4 \mathrm{a}$ \\
\hline & & $\mathrm{T}$ & & & $\mathrm{S}$ & 16 & $33.1 \mathrm{a}$ \\
\hline & & S & & & $\mathrm{T}$ & 3 & $34.6 \mathrm{a}$ \\
\hline & & $\mathrm{S}$ & & & $\mathrm{S}$ & 35 & $8.1 \mathrm{~b}$ \\
\hline Xbarc57 & $3 \mathrm{~A}$ & $\mathrm{~T}$ & Xgwm397 & $4 \mathrm{~A}$ & $\mathrm{~T}$ & 28 & $42.5 \mathrm{a}$ \\
\hline & & $\mathrm{T}$ & & & $\mathrm{S}$ & 9 & $28.5 b$ \\
\hline & & $\mathrm{S}$ & & & $\mathrm{T}$ & 18 & $12.7 \mathrm{c}$ \\
\hline & & $\mathrm{S}$ & & & $\mathrm{S}$ & 22 & $9.1 \mathrm{c}$ \\
\hline Xbarc321 & $3 \mathrm{~A}$ & $\mathrm{~T}$ & Xgwm269 & $4 \mathrm{~A}$ & $\mathrm{~T}$ & 20 & $44.1 \mathrm{a}$ \\
\hline & & $\mathrm{T}$ & & & $\mathrm{S}$ & 34 & $24.0 \mathrm{~b}$ \\
\hline & & $\mathrm{S}$ & & & $\mathrm{T}$ & 3 & $34.6 \mathrm{ab}$ \\
\hline & & $\mathrm{S}$ & & & $\mathrm{S}$ & 25 & $8.9 \mathrm{c}$ \\
\hline Xbarc321 & $3 \mathrm{~A}$ & $\mathrm{~T}$ & Xgwm397 & $4 \mathrm{~A}$ & $\mathrm{~T}$ & 38 & $36.3 \mathrm{a}$ \\
\hline & & $\mathrm{T}$ & & & $\mathrm{S}$ & 19 & $23.0 \mathrm{~b}$ \\
\hline & & S & & & $\mathrm{T}$ & 13 & $19.0 \mathrm{~b}$ \\
\hline & & $\mathrm{S}$ & & & $\mathrm{S}$ & 16 & $6.6 \mathrm{c}$ \\
\hline
\end{tabular}

${ }^{1}$ Putative phenotypic effect from single-locus analysis (see Table 5).

Means followed by the same letter were not significantly different, $\mathrm{P}<0.05$.

that the effects of QPhs.pseru-2B2 are relatively minor. Perhaps in this particular genetic background, the effects of 2B QTLs on enhanced tolerance are large enough that any additional effects of loci on $3 \mathrm{~A}$ are obscured, difficult to detect with the number of lines evaluated, or additional, unknown loci exert epistatic effects that mask those of the $3 \mathrm{~A}$ genes.
As noted by Liu et al. (2008), 'Rio Blanco' has served as a foundation cultivar for North American hard white winter wheat breeding programmes. QPhs.pseru-3AS likely now is widespread in such programmes, and selection for tolerant marker alleles linked to it should result in a net increase in tolerance to preharvest sprouting. 
Table 7: Mean sprouting tolerance of genotypes identified by two independent loci within NW97S186/Rio Blanco

\begin{tabular}{|c|c|c|c|c|c|c|c|}
\hline Locus 1 & Chromosome & $\begin{array}{c}\text { Putative } \\
\text { phenotype }^{1}\end{array}$ & Locus 2 & Chromosome & $\begin{array}{c}\text { Putative } \\
\text { phenotype }^{1}\end{array}$ & $\begin{array}{l}\text { No. } \\
\text { lines }\end{array}$ & $\begin{array}{c}\text { Tolerance } \\
\text { (mean) }\end{array}$ \\
\hline \multirow[t]{4}{*}{ Xbarc105 } & \multirow[t]{4}{*}{$2 \mathrm{~B}$} & $\mathrm{~T}$ & \multirow[t]{4}{*}{ Xbarc012 } & \multirow[t]{4}{*}{$3 \mathrm{~A}$} & $\mathrm{~T}$ & 29 & $27.3 \mathrm{a}$ \\
\hline & & $\mathrm{T}$ & & & $\mathrm{S}$ & 32 & $21.6 \mathrm{a}$ \\
\hline & & $\mathrm{S}$ & & & $\mathrm{T}$ & 28 & $22.4 \mathrm{a}$ \\
\hline & & S & & & S & 20 & $10.0 \mathrm{~b}$ \\
\hline \multirow[t]{4}{*}{ Xbarc105 } & \multirow[t]{4}{*}{$2 \mathrm{~B}$} & $\mathrm{~T}$ & \multirow[t]{4}{*}{ Xbarc321 } & \multirow[t]{4}{*}{$3 \mathrm{~A}$} & $\mathrm{~T}$ & 49 & $24.7 \mathrm{a}$ \\
\hline & & $\mathrm{T}$ & & & S & 24 & $19.8 \mathrm{a}$ \\
\hline & & $\mathrm{S}$ & & & $\mathrm{T}$ & 41 & $20.9 \mathrm{a}$ \\
\hline & & $\mathrm{S}$ & & & $\mathrm{S}$ & 13 & $10.5 b$ \\
\hline \multirow[t]{4}{*}{ Xbarc105 } & \multirow[t]{4}{*}{$2 \mathrm{~B}$} & $\mathrm{~T}$ & \multirow[t]{4}{*}{ Xbarc57 } & \multirow[t]{4}{*}{$3 \mathrm{~A}$} & $\mathrm{~T}$ & 35 & $25.3 \mathrm{a}$ \\
\hline & & $\mathrm{T}$ & & & S & 35 & $20.9 \mathrm{a}$ \\
\hline & & $\mathrm{S}$ & & & $\mathrm{T}$ & 32 & $22.9 \mathrm{a}$ \\
\hline & & $S$ & & & $S$ & 18 & $9.4 b$ \\
\hline
\end{tabular}

${ }^{1}$ Putative phenotypic effect from single-locus analysis (see Table 5).

Means followed by the same letter were not significantly different, $\mathrm{P}<0.05$.

\section{References}

Biddulph, T. B., J. A. Plummer, T. L. Setter, and D. J. Mares, 2008: Seasonal conditions influence dormancy and preharvest sprouting tolerance of wheat (Triticum aestivum L) in the field. Field Crops Res. 107, 116-128.

Brijs, K., C. M. Courtin, H. Goesaert, K. Gebruers, J. A. Delcour, P. R. Shewry, R. J. Henry, J. Nicolas, J. Potus, R. Garcia, and S. Davidou. 2009. Enzymes and enzymes inhibitors endogenous to wheat. In: K. Khan, and P. R. Shewry (eds), Wheat: Chemistry and Technology, 401-436. AACC International, Inc., St. Paul, MN.

Clarke, F. R., J. M. Clarke, R. M. DePauw, M. R. Fernandez, S. Fox, J. Gilbert, G. Humphreys, R. E. Knox, T. N. McCaig, D. Procunier, M. Sissons, and D. Somers, 2005: Strategic approach to mitigating weather induced defects of wheat quality. Euphytica 143, 285-290.

DePauw, R. M., R. E. Knox, A. K. Singh, S. L. Fox, D. G. Humphreys, and P. Hucl, 2012: Developing standardized methods for breeding preharvest sprouting resistant wheat, challenges and successes in Canadian wheat. Euphytica 188, 7-14.

Graybosch, R. A., C. J. Peterson, P. S. Baenziger, L. A. Nelson, B. B. Beecher, D. B. Baltensperger, and J. M. Krall, 2005: Registration of 'Arrowsmith' hard white winter wheat. Crop Sci. 45, 1662-1663.

Gupta, P., H. Balyan, K. Edwards, P. Isaac, V. Korzun, M. Röder, M.-F. Gautier, P. Joudrier, A. Schlatter, J. Dubcovsky, R. De la Pena, M. Khairallah, G. Penner, M. Hayden, P. Sharp, B. Keller, R. Wang, J. Hardouin, P. Jack, and P. Leroy, 2002: Genetic mapping of 66 new microsatellite (SSR) loci in bread wheat. Theor. Appl. Genet. 105, $413-422$.

Ibrahim, A., M. Langham, J. Rickertsen, S. Kalsbeck, R. Little, S. Haley, P. Baenziger, O. K. Chung, B. W. Seabourn, Y. Jin, D. V. Mcvey, and G. Bai, 2008: Registration of 'Darrell' wheat. J. Plant Reg. 2, 115 -121 .

Kato, K., W. Nakamura, T. Tabiki, H. Miura, and S. Sawada, 2001: Detection of loci controlling seed dormancy on group 4 chromosomes of wheat and comparative mapping with rice and barley genomes. Theor. Appl. Genet. 102, 980-985.

Kottearachchi, N. S., N. Uchino, K. Kato, and H. Miura, 2006: Increased grain dormancy in white-grained wheat by introgression of preharvest sprouting tolerance QTLs. Euphytica 152, 421-428.

Kulwal, P. L., R. Singh, H. S. Balyan, and P. K. Gupta, 2004: Genetic basis of pre-harvest sprouting tolerance using single-locus and twolocus QTL analyses in bread wheat. Funct. Integr. Genomics 4, 94-101.

Kulwal, P. L. N., A. Kumar, P. Gaur, J. P. Khurana, A. K. Khurana, H. S. Balyan. Tyagi, and P. K. Gupta, 2005: Mapping of a major QTL for pre-harvest sprouting tolerance on chromosome $3 \mathrm{~A}$ in bread wheat. Theor. Appl. Genet. 111, 1052-1059.

Liu, S., S. Cai, R. A. Graybosch, C. Chen, and G. Bai, 2008: Quantitative trait loci for resistance to pre-harvest sprouting in US hard white winter wheat Rio Blanco. Theor. Appl. Genet. 117, 691—699.
Mares, D., and K. Mrva, 2001: Mapping quantitative trait loci associated with variation in grain dormancy in Australian wheat. Aust. J. Agric. Res. 52, 1257-1265.

Mares, D., K. Mrva, J. Cheong, K. Williams, B. Watson, E. Storlie, M. Sutherland, and Y. Zou, 2005: A QTL located on chromosome 4A associated with dormancy in white- and red-grained wheats of diverse origin. Theor. Appl. Genet. 111, 1357-1364.

Morris, C. F., and G. L. Paulsen, 1992: Review: research on pre-harvest sprouting resistance in hard red and white winter wheats at Kansas State University. In: M. K. Walker-Simmons, and J. L. Reid (eds), Pre-Harvest Sprouting in Cereals 1992, 113-120. Am. Assoc. of Cereal Chemists, St. Paul, MN.

Morris, C. F., J. M. Moffat, R. G. Sears, and G. M. Paulsen, 1989: Seed dormancy and responses of caryopses, embryos and calli to abscisic acid in wheat. Plant Physiol. 90, 643-647.

Munkvold, J. D., J. Tanaka, D. Benscher, and M. E. Sorrells, 2009: Mapping quantitative trait loci for preharvest sprouting resistance in white wheat. Theor. Appl. Genet. 119, 1223-1235.

Pestsova, E., M. W. Ganal, and M. S. Röder, 2000: Isolation and mapping of microsatellite markers specific for the D genome of bread wheat. Genome 43, 689—697.

Rasul, G., G. D. Humphreys, J. Wu, A. Brûlé-Babel, B. Fofana, and K. D. Glover, 2012: Evaluation of preharvest sprouting traits in a collection of spring wheat germplasm using genotype and genotype $\times$ environment interaction model. Plant Breed. 131, 244-251.

Röder, M. S., V. Korzun, K. Wandehake, J. Planschke, M. H. Tixier, P. Leroy, and M. W. Ganal, 1998: A microsatellite map of wheat. Genetics 149, 2007-2023.

Ross, A. S., and A. D. Bettge, 2009: Passing the test of wheat end-use quality. In: B. F. Carver (ed.), Wheat: Science and Trade, 455-493. Wiley-Blackwell, Danvers, MA.

Singh, R., M. Matus-Cádiz, M. Båga, P. Hucl, and R. N. Chibbar, 2010: Identification of genomic regions associated with seed dormancy in white-grained wheat. Euphytica 174, 391-408.

Singh, R., P. Hucl, M. Båga, and R. N. Chibbar, 2012: Validation of molecular markers for pre-harvest sprouting resistance in bread wheat. Cereal Res. Commun. 40, 194-204.

Tan, M.-K., P. J. Sharp, M.-Q. Lu, and N. Howes, 2006: Genetics of grain dormancy in a white wheat. Aust. J. Agric. Res. 57, 11571165.

Torada, A., M. Koike, S. Ikeguchi, and I. Tsutsui, 2008: Mapping of a major locus controlling seed dormancy using backcrossed progenies in wheat (Triticum aestivum L.). Genome 51, 426-432.

Wu, J., and B. F. Carver, 1999: Sprout damage and preharvest sprout resistance in hard white winter wheat. Crop Sci. 39, 441- 447.

Xie, K., L. Jiang, B. Lu, C. Yang, L. Li, X. Liu, L. Zhang, Z. Zhao, and J. Wan, 2011: Identification of QTLs for seed dormancy in rice (Oryza sativa L.). Plant Breed. 130, 328-332. 